\title{
Customer segment transition through the customer loyalty program
}

\author{
Makoto Kimura \\ Department of Business Administration, \\ Niigata University of International and Information Studies, Niigata, Japan
}

\begin{abstract}
Purpose - This study presents the applicability of a model-based approach for loyalty program forecasting using smartphone app in the digital strategy of the retail industry.

Design/methodology/approach - The authors develop a dynamic model with the cyclical structure of customer segments through customer experience. They use time-series data on the number of members of the loyalty program, "Seven Mile Program" and confirm the validity of the approximate calculation of customer segment share, customer segment sales share and aggregate sales performance. The authors present three medium-term forecast scenarios after the launch of a smartphone payment service linked with the loyalty program.

Findings - The sum of the two customer segment shares for forecasting (the sum of the quasi-excellent and excellent customer ratios) is about $30 \%$ in each scenario, consistent with an essential customer loyalty (true loyalty) share obtained in the existing empirical study.

Research limitations/implications - Digital strategy in the retail industry should focus more on estimating and forecasting average amounts of customer segments and the number of aggregated customers through the digitalization on the customer side than on individual customer journeys and responses.

Practical implications - Multi-scenario evaluation through simulation of dynamic models from a systemic view can be used for decision-making in retailing digital strategies.

Originality/value - This study builds a model that integrates the cyclicality of customer segment transition through customer experiences into a loyalty matrix framework, which is a method that has previously been used in the hospitality industry.
\end{abstract}

Keywords Customer journey, Customer loyalty, Smartphone app, Digital strategy, Forecasting,

System dynamics

Paper type Research paper

\section{Introduction}

The conceptualization of the customer journey during the pre-purchase, purchase and postpurchase stages has been shown based on the theory of market or business strategy (Handarkho, 2020; Lemon and Verhoef, 2016; Grewal and Roggeveen, 2020). Recent empirical studies have focused on touchpoints across multichannel or omnichannel retailing, and largescale data analysis based on the static models of the customer journey have provided implications for customer segments and customer experience management (de Haan et al., 2018; Chen et al., 2019; Handarkho, 2020; Jo et al., 2020). However, the existing empirical research models rarely consider the transitions between customer segments and the performance forecast by all customers in the customer journey. This study traces how the customer segment size (cumulative sum), based on the customer loyalty classification,

(C) Makoto Kimura. Published by Emerald Publishing Limited. This article is published under the Creative Commons Attribution (CC BY 4.0) licence. Anyone may reproduce, distribute, translate and create derivative works of this article (for both commercial and non-commercial purposes), subject to full attribution to the original publication and authors. The full terms of this licence may be seen at http://creativecommons.org/licences/by/4.0/legalcode

Funding: This work was supported by JSPS KAKENHI Grant Numbers JP17K04017, JP19H01534.
Received 3 September 2020 Revised 29 December 2020 6 February 2021 9 April 2021 Accepted 4 May 2021 
APJML 34,3

\section{2}

changes over time. It proposes a dynamic model that captures the whole loop structure and non-linearity of performance (Grewal and Roggeveen, 2020) from a systemic view rather than individual customer journeys. "A systematic view" means that this study does not focus on tracking the path of each customer over multiple touchpoints, as described in previous literature, but is focused on approximate calculations of population migration (time transitions) and aggregated purchase amounts that take into account the circulation between customer loyalty segmentation through multiple types of customer experiences.

Using a single case analysis, we select a loyalty program ("Seven Mile Program") launched by Seven and i Holdings (2019a), the largest retailer in Japan, in 2018 as a smartphone app for customers of the physical stores. Through the approximate calculation of the number of Seven Mile Program members and the overall business performance using the published data, we attempt to estimate the purchase amounts by customer segment and further forecast the performance as the business scenarios.

Digital strategy refers to a business and/or corporate strategy that focus on digitalization. The essence of digital strategy requires consideration of the transition from quantitative change to qualitative change (understood as digital transformation) as a competitive advantage through three types of core digitalization processes: expression, connectivity and aggregation. Digital transformation from a business perspective includes shifting from a focus on responding to customer demand, choices and preferences to a focus on forecasting (Adner et al., 2019). Consumers constantly use smartphones in daily life and can update the combination of services used and their current circumstances. One of the retailers' digital strategies is adopting a loyalty program using a smartphone app. The diffusion of loyalty programs by smartphone apps in the retail business may transform the customer experience in all stages, change the customer journey (de Haan et al., 2018; Handarkho, 2020) and result in profound customer engagement (Pansari and Kumar, 2017).

This study refers to a loyalty program ("Seven Mile Program") across the retail group companies of Seven and i Holdings (Seven and i) as the single case of the digital strategy in the retailindustry. Seven and iisa pure holding company of group companies, including convenience stores, superstores, department stores, supermarkets and financial services in Japan.

Seven and i realized the unification of customer identifications for the group companies and called it 7iD. Since June 2018, the Seven Mile Program, a loyalty program for group companies, has been in full operation. This loyalty program allows its users to log in to the iOS and Android smartphone apps provided by each group company using 7iD, enabling a unified view of customer purchase information across group companies and stores. Thus, the 7iD-based data integration platform made it possible to conduct customer analysis across the group companies (Ryutsuu News, 2018a, b).

\section{Related prior research}

Customer journey and customer engagement (CE)

Lemon and Verhoef (2016) describe the customer journey as all processes that a customer goes through across all stages (pre-purchase, purchase and post-purchase stages) and touchpoints that make up the customer experience. They also indicate that the overall approach to modeling the customer journey has two options: an aggregated sales model and an individual behavior attribute model. Previous empirical research mainly focused on the customer journey models (CJMs) using online behavior records and e-commerce data and argued for the interdependence between multiple channels and customer behaviors (Chen et al., 2019; Handarkho, 2020).

In the marketing field, $\mathrm{CE}$ is a common term meaning "customer activity that targets a company." According to Pansari and Kumar (2017, p. 295), CE is defined as "the mechanics of a customer's value addition to the firm, either through direct or/and indirect contribution." 
van Heerde et al. (2019) conducted an empirical study of retail mobile apps and CE. They developed the purchase model (a probit model) for each customer based on the access records and purchase data and estimated the annual revenue amount assuming an average transaction value of US\$100 per customer and a total sales amount for 100,000 people.

\section{Customer loyalty and the loyalty program}

More recently, retailers have adopted customer loyalty programs that have long been used by the travel, hospitality and leisure industries. Customer loyalty is one critical key to retail business success, and retaining an existing customer costs far less than acquiring new ones. One way to do this is to create customer loyalty programs that effectively reward the bestor potentially important - customers. Further, these program participants will spend more than the non-participants (Gable et al., 2008).

Customer loyalty has a complex multidimensional structure involving behavioral (repeat purchases) and attitudinal components (Dick and Basu, 1994; Bowen and Shoemaker, 1998). Bowen and Shoemaker (1998) claim that loyalty is the likelihood of a customer returning and their willingness to behave as a partner to the organization. Loyalty programs are designed to cultivate customer loyalty by rewarding repeat purchases. Members of a loyalty program reap a wide variety of "hard" benefits (e.g. discounts, coupons and rebates for past purchases) and "soft" benefits (e.g. special invitations, shopping convenience, and therefore are likely to become dedicated patrons of a store (Gable et al., 2008; Pan et al., 2012)). Customer loyalty program membership tends to enhance customer loyalty (Tanford and Baloglu, 2012). Baloglu (2002) presents the loyalty matrix that shows four loyalty levels (segments): high (true) loyalty, latent loyalty, spurious loyalty and low (no) loyalty, based on the crossclassification of attitudinal levels that represents the degree of psychological attachment and the behavioral level that represents repeat patronage.

Customers with high (true) loyalty are characterized by a strong emotional attachment to the company and frequent patronage. Latent loyalty is a strong emotional attachment accompanied by low usage. Spurious loyalty is repeat patronage without emotional commitment, typically motivated by convenience or lack of alternatives. Low (no) loyalty is low patronage and a lack of emotional attachment (Tanford and Baloglu, 2012). Tanford and Baloglu conducted a multivariate analysis of variance on the questionnaire response data of 261 casino loyalty program members in Las Vegas, USA, and attained the validity of the royalty matrix as follows: true loyalty $(36.8 \%)$, latent loyalty $(28.4 \%)$, spurious loyalty $(12.3 \%)$ and low loyalty (22.6\%). Tanford and Malek (2015) demonstrated the validity of the loyalty matrix with hotel customers. They further suggested that the loyalty matrix has utility as a general framework for understanding hospitality loyalty and is applicable to other segments such as restaurants and cruises.

\section{Digital strategy case description}

Seven and i launched the cross-group website "Omni 7" in November 2015 and unified the customer ID online. At that time, Seven and i was promoting an "omni-strategy" centered on e-commerce as the group's digital strategy. However, in 2018, the policy was revised into "a customer relationship management strategy (CRM) that strengthens the relationship with approximately 24 million customers who visit the group stores every day" (Seven and i, 2019a, p. 44). The "Seven Mile Program," the Seven and i loyalty program, began operating in June 2018. The Seven Mile Program uses the common identifier "7iD" to provide customers with miles according to the quantities purchased and their purchase behavior at each subsidiary of the group and provides rewards through rankings. 7iD also unified the customer IDs of real stores, and customers can use 7iD to log in on mobile apps for the "Seven- 
APJML 34,3

\section{4}

Figure 1. Customer segment transition model
Eleven" convenience store, the "Ito-Yokado" supermarket, and "Omni 7", which have all been operating since June 2018. Seven and i has announced that by using the common identifier 7iD, the quantity purchased at each subsidiary store will be linked to foster loyalty and promote mutual customer transfer between the real store and the internet. Moreover, the "Seibu and SOGO" department store app was launched in December 2018. As of the end of April 2019, the total number of 7iD members was 14.68 million (Seven and i, 2019a, p. 45).

Using the usage data of the Seven Mile Program, Seven and i performs a customer analysis using six customer segments: "excellent," "quasi-excellent," "low-frequency highpurchasing (LFHP)," "high-frequency low-purchasing (HFLP)," "growth" and "entry." The results of the composition ratio are as follows: excellent 7.5\%, quasi-excellent $14.1 \%$, LFHP $7.6 \%$, HFLP $20.6 \%$, growth $37.8 \%$ and entry $12.5 \%$. Furthermore, the results of the purchase amount composition ratio are as follows: excellent $30.9 \%$, quasi-excellent $26.5 \%$, LFHP $16.7 \%$, HFLP $12.1 \%$, growth $12.8 \%$ and entry $0.8 \%$. Seven and i creates a customer segmentation map every month, captures the movement of $7 \mathrm{iD}$ members and plans and implements countermeasures (Ryutsuu News, 2019a, b). As of the end of February 2019, Seven and i had a group-wide store network of approximately 22,400 stores in Japan (Seven and i, 2019a).

Seven and i initially aimed to accumulate 30 million $7 \mathrm{iD}$ members in 2020 by launching the smartphone barcode payment service "7pay" as a new service linked to the Seven Mile Program from July 2019. However, shortly after the service was launched, there were reports of unauthorized access granted to some accounts. The 7pay service was abolished by the end of September 2019 due to several factors, including the time it took to respond to the unauthorized access granted to these accounts (Seven and i, 2019b).

\section{Model}

Customer segment transition model through a loyalty program

We attempt to build the customer segment transition model by integrating the loyalty matrix by Baloglu and the six customer segments of Seven Mile Program members (see Figure 1).

To transform the loyalty matrix from a static stationary model to a dynamic customer state transition model, we add several states to reach true loyalty via high loyalty and to enter the loyalty program. Moreover, we add paths representing customer segment transitions. These paths are drawn using the arrow (tip and line) in this model. The direction of the arrow (tip) indicates the direction (forward-typed or backward-typed) of the time transition of customer loyalty and customer segments through the loyalty program member's customer experience. The arrow lines indicate the customer experience that triggers the segment

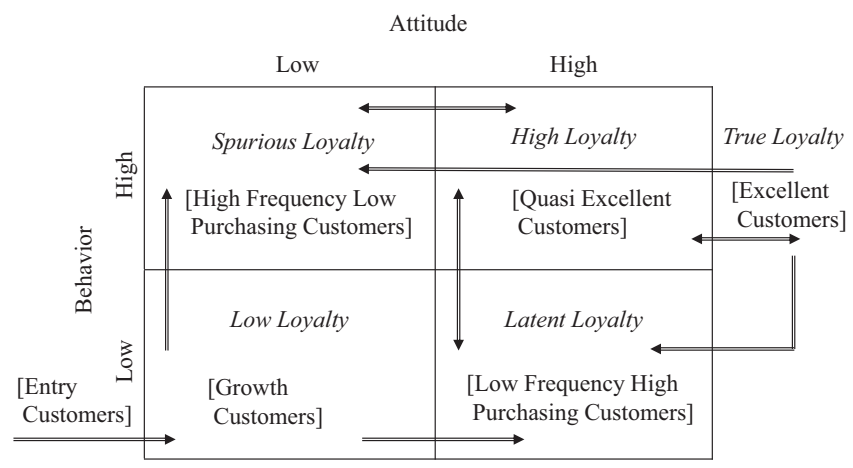


transition. The correspondence between the customer loyalty categories and the customer segments of the loyalty program shown in this model is described below.

The Seven Mile Program's entry customers first move to growth customers through purchasing activities. Next, they shift to HFLP customers classified as spurious loyalty or LFHP customers of latent loyalty. LFHP customers and HFLP customers can move to quasiexcellent customers who are classified as high loyalty through their customer experience. Reverse cases are also possible: High loyalty's quasi-excellent customers can become excellent true loyalty customers through further customer experience and elapsed time. The opposite case is also possible. In this model, the state change in which both the behavior and attitude - the two dimensions of customer loyalty — simultaneously return to the low level is interpreted as the loyalty program "churn." Table 1 shows a list of customer experience names distinguished by this model.

\section{System dynamics model}

The customer segment transition model can be transformed into a system dynamics (SD) model that performs the numerical time integration. SD is a system modeling and simulation method proposed by Forrester (1961). SD can graphically model a stock variable (cumulative variable), the input/output flow variables that act on a stock and feedback between other variables (circulation effect). As a pipeline structure consisting of stock and flow variables, a cyclical structure combining a customer loyalty promotion chain can also be modeled, representing a chain of different loyalty levels (stock variables) and a demotion chain that includes customer churn (see Figure 2, Figure 5).

\section{Stock and flow variables}

The customer segments shown in the customer segment transition model are converted into the SD model's stock variables. The initial value of each customer segment, which is a stock variable including the time term $t$, is zero but changes over time due to the influence of customer experience, which is an input/output flow variable. Customer experience appears as a flow variable in the SD model. The formula of stock and flow variables is shown in Table 2.

\begin{tabular}{|c|c|c|}
\hline Transition between customer segments & $\begin{array}{l}\text { Customer experience for } \\
\text { forward type }\end{array}$ & $\begin{array}{l}\text { Customer experience for } \\
\text { backward type }\end{array}$ \\
\hline Potential customers, entry customers & New entry & \\
\hline Entry customers, growth customers & Low loyalty experience & \\
\hline $\begin{array}{l}\text { Growth customers, high-frequency low- } \\
\text { purchasing customers }\end{array}$ & HFLP experience & \\
\hline $\begin{array}{l}\text { Growth customers, low-frequency high- } \\
\text { purchasing customers }\end{array}$ & LFHP experience & \\
\hline $\begin{array}{l}\text { High-frequency low-purchasing customers, } \\
\text { quasi-excellent customers }\end{array}$ & $\begin{array}{l}\text { HFLP to high loyalty } \\
\text { experience }\end{array}$ & $\begin{array}{l}\text { Backward spurious loyalty } \\
\text { experience }\end{array}$ \\
\hline $\begin{array}{l}\text { Low-frequency high-purchasing customers, } \\
\text { quasi-excellent customers }\end{array}$ & $\begin{array}{l}\text { LFHP to High loyalty } \\
\text { experience }\end{array}$ & $\begin{array}{l}\text { Backward latent loyalty } \\
\text { experience }\end{array}$ \\
\hline $\begin{array}{l}\text { Quasi-excellent customers, excellent } \\
\text { customers }\end{array}$ & True loyalty experience & $\begin{array}{l}\text { Backward high loyalty } \\
\text { experience }\end{array}$ \\
\hline $\begin{array}{l}\text { High-frequency low-purchasing customers, } \\
\text { excellent customers }\end{array}$ & & $\begin{array}{l}\text { Leap backward spurious } \\
\text { loyalty experience }\end{array}$ \\
\hline $\begin{array}{l}\text { Low-frequency high-purchasing customers, } \\
\text { excellent customers }\end{array}$ & & $\begin{array}{l}\text { Leap backward latent loyalty } \\
\text { experience }\end{array}$ \\
\hline
\end{tabular}

Note(s): HFLP is high-frequency low-purchasing; LFHP is low-frequency high-purchasing

Table 1.

Customer experience segments 
APJML

34,3

616

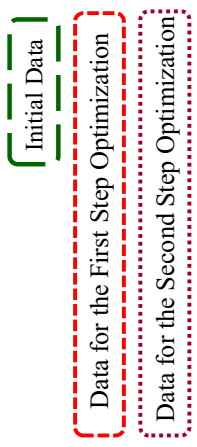
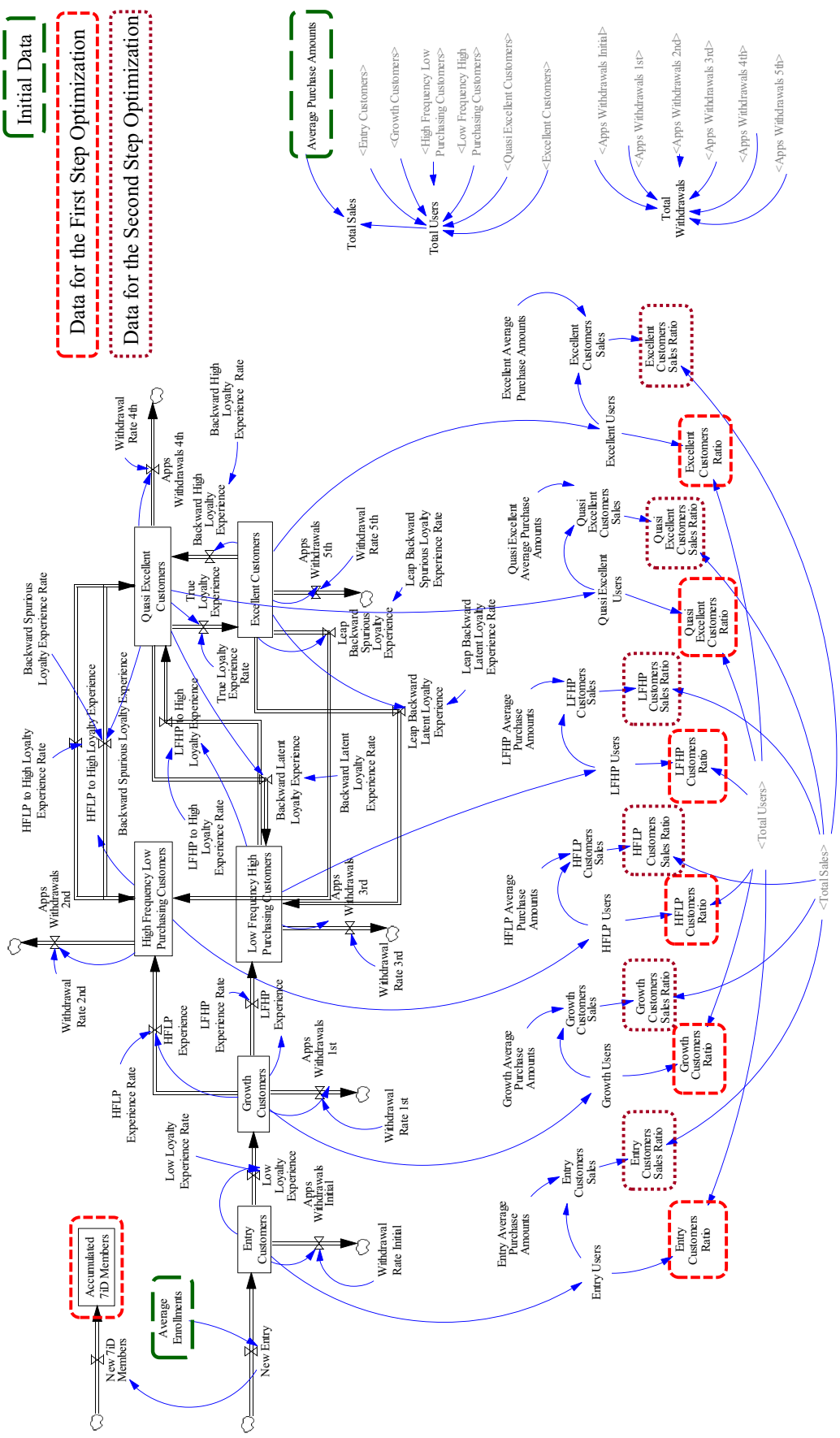

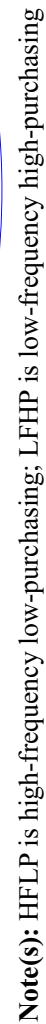

Figure 2.
System dynamics (SD) model (for the stationary model) 


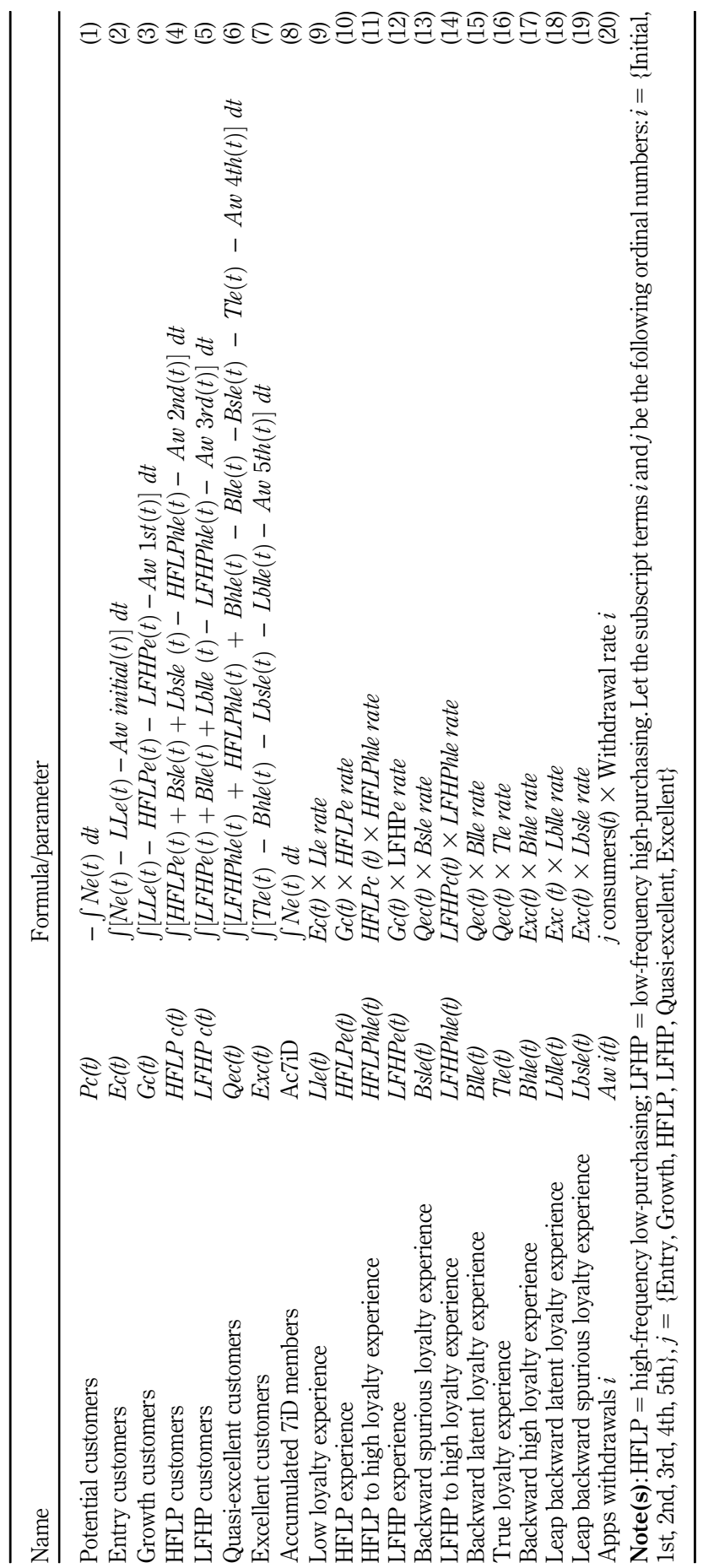

Table 2

Formula for the stock and flow variable 


\section{APJML 34,3}

Aggregation variables

The customer ratio and the sales ratio in each customer segment are calculated as an aggregation variable for model calibration. The average purchase amount is given as an initial value. The definition formulas using subscript $j$ and the time term $t$ are as follows:

$$
\text { Total users }(t)=\sum j \text { customers }(t)
$$

$$
\begin{gathered}
\text { Total sales }(t)=\text { Total users }(t) \times \text { Average purchase amounts } \\
j \text { customer ratio }(t)=j \text { customers }(t) / \operatorname{Total} \text { users }(t) \\
j \text { total sales }(t)=j \text { average purchase amounts } \times j \text { customers }(t) \\
j \text { sales ratio }(t)=j \text { total sales }(t) / \text { Total sales }(t)
\end{gathered}
$$

\section{Stationary model and incremental model}

New entry, one option of the customer experience flow variable, is defined as a constant or time variable. When new entry uses constant definition formulas, we refer to a stationary model; when new entry uses variable definition formulas, we refer to an incremental model. The stock variable, potential customers $(t)$, is a component of the incremental model. The definition formula of new entry using the time term $t$ is as follows:

Stationary model:

$$
\text { New entry }(t)=\text { Average enrollments }
$$

Incremental model:

$$
\begin{aligned}
\text { New entry }(t) & =\text { Adoption rate } \times \text { Contact rate } \\
& \times \text { Total users }(t) \times \frac{\text { Potential customers }(t)}{(\text { Potential customers }(t)+\text { Total users }(t))}
\end{aligned}
$$

Formula (27) includes only the internal influence of external and internal influences (Mahajan et al., 1990), which are components of the Bass model (Bass, 1969). The internal influence is included in new entry at this time due to contact between potential customers and existing customers; the same definition formulas apply, resulting from the word-of-mouth effect.

\section{Results}

\section{Initial value setting}

Time-series data are analyzed for 48 weeks from June 2018, when the 7iD member service started, to the end of April 2019 (start time, zero; end time, 47). The initial value for average enrollments $(212,766)$ used in the stationary model is calculated by dividing this period's increase in $7 \mathrm{iD}$ members. The average purchase amount (JP $¥ 1,808.25$ ) is attained by dividing the 7iD members’ average monthly purchase amount $(J P ¥ 7,233)$ by 4 weeks. The initial value of potential customers (4.68e +06 [Person $\times$ Week]) used in the incremental model is set using the number of Nanaco electronic money cards issued by Seven and i as a proxy for the number of users (issued numbers of Nanaco until $2019 \times$ potential diffusion rate). The Euler method of numerical integration is used, and the time interval, where the time step is a week, is set to 0.015625 .

\section{Parameter optimization by model calibration}

The two models are calibrated in two steps, and the parameters are optimized (see Figure 2). The first step is parameter optimization using time-series data of accumulated 7iD members 
and customer ratio data for each customer segment. In the second step, after setting the parameter values attained in the first step as initial values, the sales ratio data are used to optimize the average purchase amounts for each customer segment. The modified Powell algorithm is used as the multidimensional iterative calculation method for parameter optimization. This algorithm is a type of conjugate gradient method that uses the payoff function for the squared error between the value calculated and the value of the actual data over the time integration interval with 95\% confidence intervals for each parameter, implemented in Ventana System's Vensim software. Table 3 shows the list of optimal parameter values.

The average purchase amounts corresponding to customer segments and/or customer loyalty also increase with the state transition. The LFHP average purchase amounts of latent loyalty are four times higher than the HFLP average purchase amounts of spurious loyalty. Excellent average purchase amounts corresponding to true loyalty are JP $¥ 7,500$ per week (JP¥390,000 per year) - twice as much as quasi-excellent average purchase amounts corresponding to high loyalty.

\section{Approximate calculation results}

Table 4 shows that the approximate results for the accumulated 7iD members have a mean absolute percentage error of less than 10\%, representing a high accuracy level (Lewis, 1982).

\begin{tabular}{|c|c|c|c|}
\hline Names & & $\begin{array}{l}\text { Stationary } \\
\text { model }\end{array}$ & $\begin{array}{l}\text { Incremental } \\
\text { model }\end{array}$ \\
\hline Potential diffusion rate [Dmnl] & & & 1 \\
\hline Adoption rate $[1 /$ Week $]$ & & & 0.0332 \\
\hline Contact rate $[1 /$ Week $]$ & & & 1 \\
\hline Low loyalty experience rate [1/Week] & Lle rate & 0.08 & 0.09 \\
\hline HFLP experience rate [1/Week] & HFLPe rate & 0.0474 & 0.0491 \\
\hline LFHP experience rate [1/Week] & LFHPe rate & 0.0198 & 0.0216 \\
\hline HFLP to high loyalty experience rate [1/Week] & HFLPe rate & 0.1 & 0.1 \\
\hline Backward spurious loyalty experience rate $[1 / \bar{W}$ Week $]$ & Bsle rate & 0.1 & 0.1 \\
\hline LFHP to high loyalty experience rate [1/Week] & $\begin{array}{l}\text { LFHPhle } \\
\text { rate }\end{array}$ & 0.1 & 0.1 \\
\hline Backward latent loyalty experience rate [1/Week] & Blle rate & 0.02 & 0.013 \\
\hline True loyalty experience rate $[1 / \mathrm{Week}]$ & Tle rate & 0.044 & 0.05 \\
\hline Backward high loyalty experience rate [1/Week] & Bhle rate & 0.01 & 0.015 \\
\hline $\begin{array}{l}\text { Leap backward latent loyalty experience rate [1/ } \\
\text { Week] }\end{array}$ & Lblle rate & 0.015 & 0.018 \\
\hline $\begin{array}{l}\text { Leap backward spurious loyalty experience rate [1/ } \\
\text { Week] }\end{array}$ & Lbsle rate & 0.01 & 0.01 \\
\hline Withdrawal rate initial [1/Week] & & 0.01 & 0.01 \\
\hline Withdrawal rate 1st [1/Week] & & 0.002 & 0.002 \\
\hline Withdrawal rate 2 nd [1/Week] & & 0.02 & 0.02 \\
\hline Withdrawal rate 3 rd [1/Week] & & 0.02 & 0.02 \\
\hline Withdrawal rate 4 th $[1 /$ Week $]$ & & 0.02 & 0.02 \\
\hline Withdrawal rate 5 th $[1 /$ Week $]$ & & 0.02 & 0.02 \\
\hline Entry average purchase amounts [Yen/Person] & & 70 & 70 \\
\hline Growth average purchase amounts [Yen/Person] & & 600 & 600 \\
\hline HFLP average purchase amounts [Yen/Person] & & 1,000 & $1,275.46$ \\
\hline LFHP average purchase amounts [Yen/Person] & & 4,000 & 4,600 \\
\hline $\begin{array}{l}\text { Quasi-Excellent average purchase amounts [Yen/ } \\
\text { Person] }\end{array}$ & & 3,200 & 3,500 \\
\hline Excellent average purchase amounts [Yen/Person] & & 7,500 & 7,500 \\
\hline
\end{tabular}

Note(s): HFLP = high-frequency low-purchasing; LFHP = low-frequency high-purchasing

Table 3. List of optimum parameter values 


\section{APJML 34,3}

\begin{tabular}{lccc}
\hline & $\begin{array}{c}\text { Stationary } \\
\text { model }\end{array}$ & $\begin{array}{c}\text { Incremental } \\
\text { model }\end{array}$ & $\begin{array}{c}\text { Data (estimated } \\
\text { values) }\end{array}$ \\
\hline Period [Week] & 48 & 48 & 48 \\
Coefficient of determination $\left(R^{2}\right)$ of accumulated & 0.9844 & 0.9959 & \\
7iD members & & & \\
MAPE of accumulated 7iD members & $4.07 \%$ & $1.17 \%$ & 0.125 \\
Entry customers ratio & 0.2264 & 0.2467 & 0.378 \\
Growth customers ratio & 0.2684 & 0.2699 & 0.206 \\
HFLP customers ratio & 0.2125 & 0.2037 & 0.076 \\
LFHP customers ratio & 0.0716 & 0.0663 & 0.141 \\
Quasi-excellent customers ratio & 0.146 & 0.139 & 0.075 \\
Excellent customers ratio & 0.075 & 0.0744 & 0.128 \\
Entry consumers sales ratio & 0.0088 & 0.0095 & 0.121 \\
Growth customers sales ratio & 0.0891 & 0.0896 & 0.167 \\
HFLP customers sales ratio & 0.1175 & 0.1437 & 0.265 \\
LFHP customers sales ratio & 0.1585 & 0.1685 & 0.309 \\
Quasi-excellent customers sales ratio & 0.2584 & 0.269 & \\
Excellent customers sales ratio & 0.3109 & 0.3088 & \\
Total sales [Thousand Yen] & $19,146,947$ & $20,537,805$ & \\
Note & &
\end{tabular}

\section{Table 4.}

Approximate calculation results of aggregated sales performance
Note(s): HFLP = high-frequency low-purchasing; LFHP = low-frequency high-purchasing; MAPE = mean absolute percentage error

Table 4 also shows a list of approximate values of the performance indicators at week 47 attained from time integration. In this case, the ratio values for each customer segment announced by Seven and i, as a result of customer analysis, were used as the data (estimated value) for the 47th week. Both models calculate a good approximation of aggregated sales performance for excellent customers and quasi-excellent customers. Figure 3 shows the transition of the accumulated 7iD members for the stationary model and the incremental model.

Figure 3.

Comparison graph of stationary and incremental models (48 weeks)

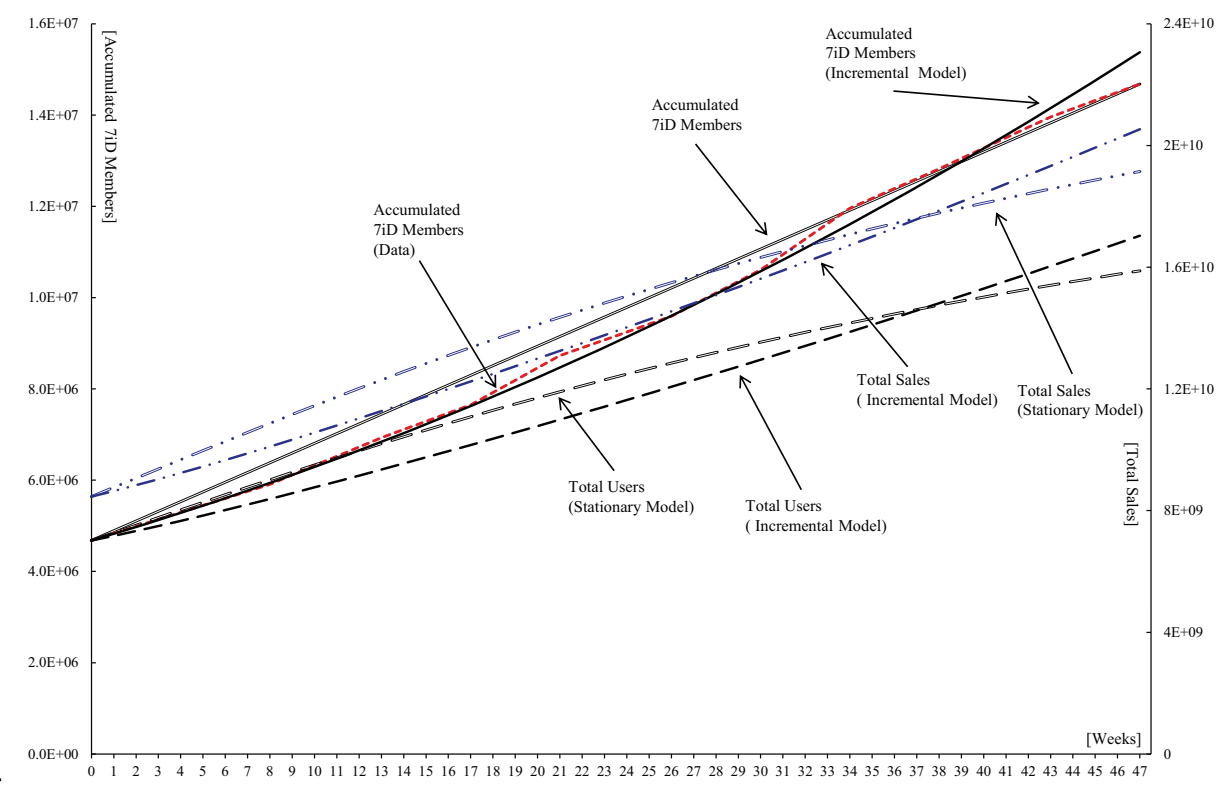


The incremental model better approximates the mean and trend of time-series data of accumulated $7 \mathrm{iD}$ members over the 48 weeks than the stationary model. However, the difference from time-series data has been increasing since week 40 . In contrast, the stationary model is a linear approximation and calculates a greater value until week 32 but calculates a good approximation after week 33. Thus, for forecasting after week 47, it may be possible to attain more appropriate prediction results from the stationary model than the incremental model. This study uses both stationary and incremental models for forecasting.

\section{Base-case scenario forecasting}

Predicted values extended from the approximate calculation results for 48 weeks using the stationary model and the incremental model to 156 weeks are shown as the base-case scenario (see Figure 4). In both models, new 7iD members represent new entry. In the stationary model, the new $7 \mathrm{iD}$ members, the accumulated $7 \mathrm{iD}$ members and the total users are increasing monotonically, and the maximum value is reached in the final week (week 156). In the incremental model, the maximum value of the new $7 \mathrm{iD}$ members $(433,032)$ is reached in week 100 (the first week of May 2020). The difference in the accumulated 7iD users in week 156 between the stationary model $(37,871,496)$ and the incremental model $(57,381,172)$ is approximately 19.51 million members. The difference in the total users in week 156 between the stationary model $(13,869,516)$ and the incremental model $(23,467,598)$ is about 9.6 million users.

\section{Sensitivity analysis with pink noise}

Informed by the scenario described above, predictive analytics are now used to forecast customer segment transition (June 2018 to May 2021) in the case that a new barcode settlement service, 7pay, continued to operate from July 2019 (week 57).

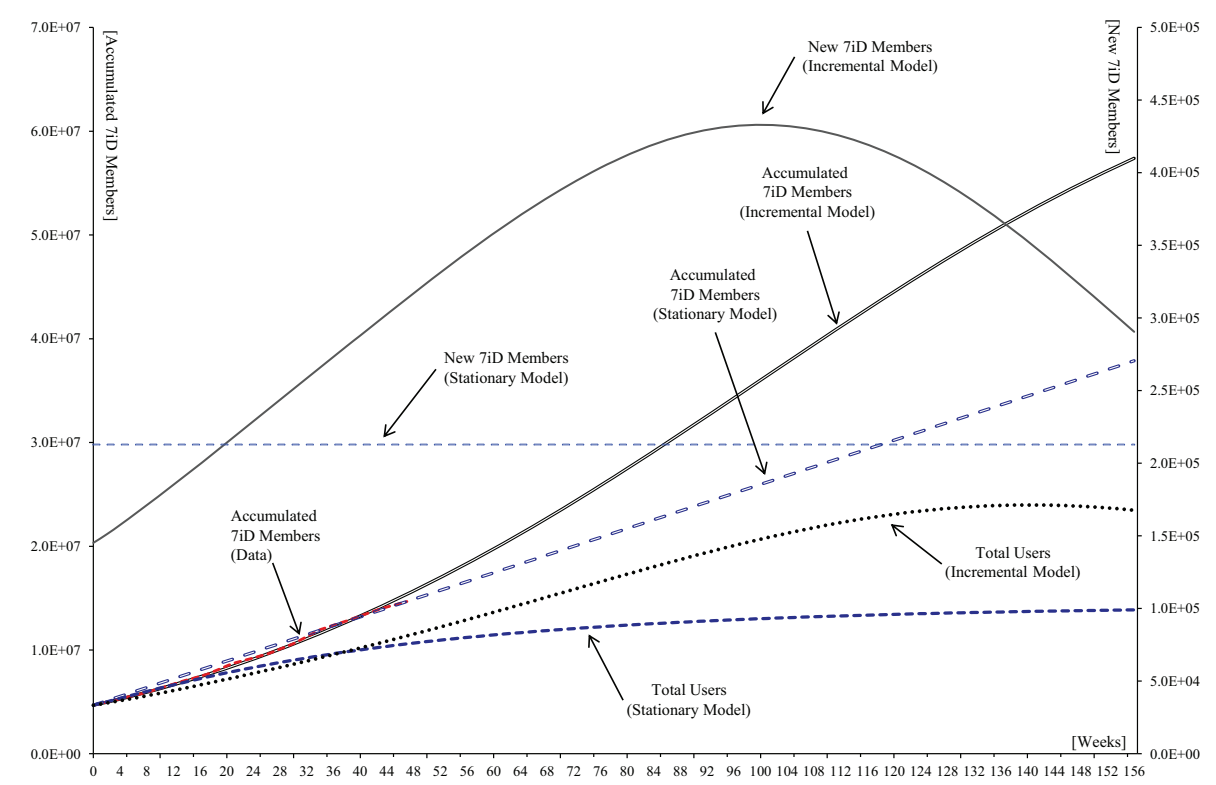

Figure 4.

Comparison graph of stationary and incremental models

(157 weeks) 
APJML

34,3

622
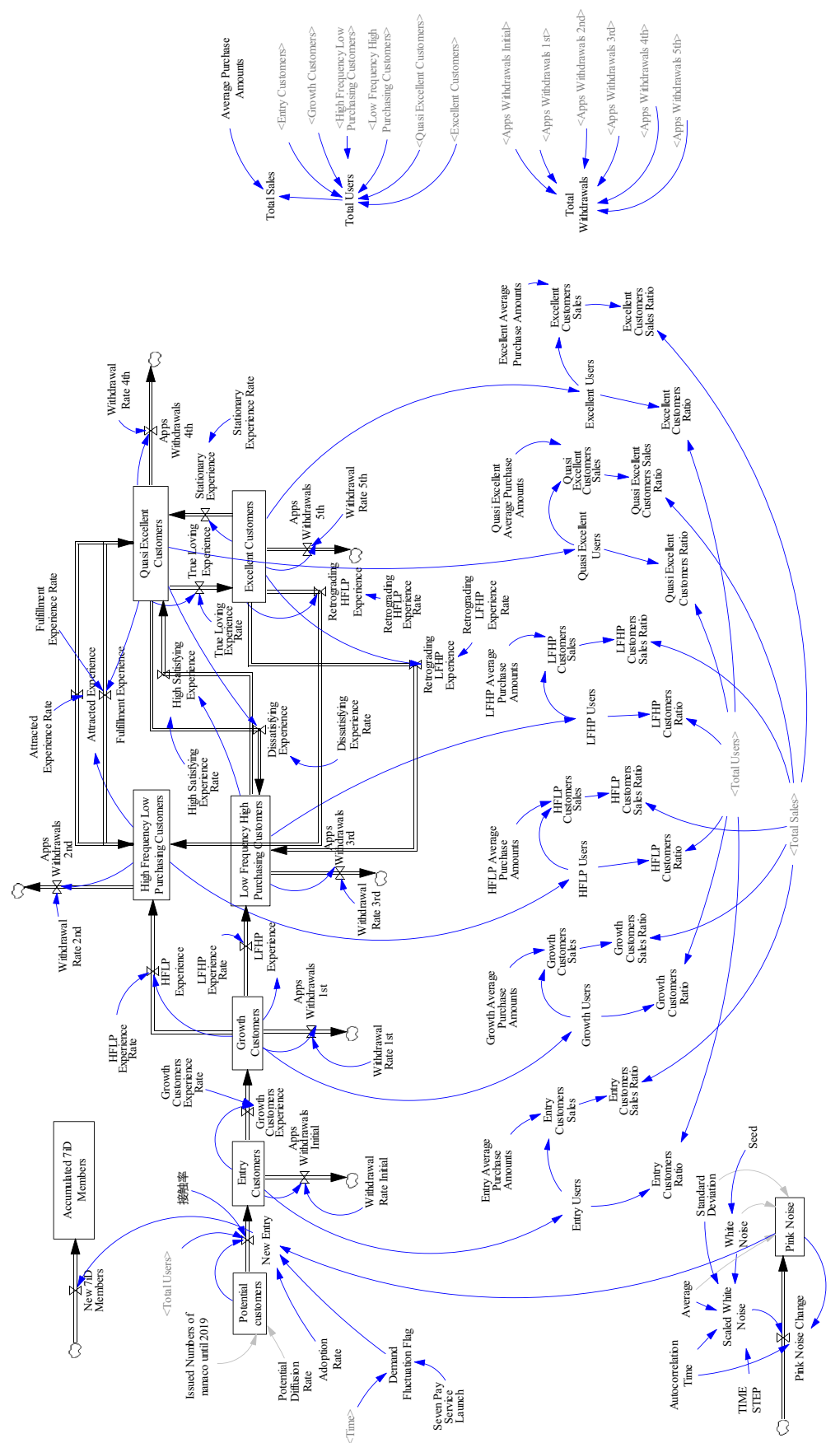

Figure 5.

Incremental model with pink noise 
Complicated processes, such as changes in consumer behavior and organizational processes over time, can be modeled as a pink noise model (Dooley and Van de Ven, 1999). Pink noise can be set as a component (variable) of the SD model for the demand fluctuation (Deif and Elmaraghy, 2009). To do this, sensitivity analysis is performed from week 57, using modified versions of the stationary and incremental models so that pink noise is multiplied as the fluctuation scale of the "New entry" (see Figure 5). A simple formulation of pink noise is firstorder exponential smoothing (first-order autocorrelation noise) using white noise. The definition formulas for pink noise generation with normally distributed random numbers as white noise $(t)$ at time $t$ are as follows (Sterman, 2000):

Scaledwhitenoise $(t)=$ Average

$$
+ \text { Whitenoise }(t) \times \text { Standarddeviation } \times \sqrt{\left(\frac{2-\frac{\text { Timestep }}{\text { Autocorrelationtime }}}{\frac{\text { Timestep }}{\text { Autocorrelationtime }}}\right)}
$$

Pinknoisechange $(t)=(\operatorname{Pinknoise}(t)-\operatorname{Scaled}$ whitenoise $(t)) /$ Autocorrelation time

$$
\begin{aligned}
& \text { Pinknoise }(t+\text { Timestep })=\operatorname{Pinknoise}(t)-\operatorname{Pinknoisechange}(t) \\
& \text { Pinknoise }(0)=\text { Average }+ \text { Standarddeviation } \times \text { Whitenoise }(0)
\end{aligned}
$$

The following values are set as initial values for sensitivity analysis: Seed $=10$ and Autocorrelation time $=4$ [Week]. The seed is a set value that allows for the generation of a normally distributed random number. A Monte Carlo simulation, in which the values of the average and standard deviation for the scaled white noise setting are changed with uniform random numbers, was executed 1,000 times. The range of both variables is as follows: $0 \leq$ standard deviation $\leq 1$, and $0.5 \leq$ average $\leq 1$.

From the sensitivity analysis results, the lower and upper limits of performance indicators at week 156 (three years later) are estimated according to the following procedure. The lower limit value is calculated by applying sensitivity analysis to the stationary model with pink noise, and the upper limit value is calculated as the 97th percentile value by applying the sensitivity analysis to the incremental model with pink noise. This corresponds to the combination of $95 \%$ confidence intervals in the sensitivity analysis of the two models. The lower and upper limits of each performance indicator can be interpreted as the worst-case

\begin{tabular}{|c|c|c|c|c|}
\hline & Worst-case scenario & Base-case scenario & Best-case scenario & \\
\hline Period [Weeks] & 157 & 157 & 157 & \\
\hline New 7iD members & 130,613 & 212,766 & 339,232 & \\
\hline Accumulated 7iD members & $29,086,978$ & $37,871,496$ & $60,223,368$ & \\
\hline Weekly total users & $9,214,877$ & $13,869,516$ & $26,658,408$ & \\
\hline Quasi-excellent customers & $1,688,943$ & $2,470,685$ & $5,028,673$ & \\
\hline Excellent customers & $1,361,950$ & $1,926,458$ & $3,584,130$ & \\
\hline Quasi-excellent customers ratio & $17.3 \%$ & $17.81 \%$ & $19.06 \%$ & Table 5. \\
\hline Excellent customers ratio & $12.6 \%$ & $13.89 \%$ & $14.77 \%$ & Estimated values of \\
\hline Quasi-excellent customers sales ratio & $30.6 \%$ & $31.52 \%$ & $36.90 \%$ & aggregated sales \\
\hline Excellent customers sales ratio & $52.4 \%$ & $57.61 \%$ & $61.26 \%$ & performance in the \\
\hline Total sales [Thousand Yen] & $16,662,800$ & $25,079,600$ & $48,205,100$ & medium-term forecast \\
\hline
\end{tabular}
and the best-case scenario, respectively. For the base scenario, the stationary model is selected because it gives a lower value. Table 5 shows a list of performance indicator values 
APJML 34,3

\section{4}

for the worst-case, base-case and best-case for a medium-term forecast. In these estimated values, the quasi-excellent customers' ratio will be between $17 \%$ and $19 \%$, and the excellent customers' ratio will be between $13 \%$ and $15 \%$.

Meanwhile, the sum of the quasi-excellent and the excellent customer ratios is about $30 \%$ in each scenario, which is consistent with the empirical results of Tanford and Baloglu (2012) for true loyalty $(36.8 \%)$ and seems to be a reasonable and achievable target value.

\section{Discussion and conclusion}

Of the medium-term forecasts shown in Table 5, the worst-case scenario corresponds to the $7 \mathrm{iD}$ forecast for FY2020, presented by Seven and i Holdings. From the dynamic model in this study, a higher number of $7 \mathrm{iD}$ members and aggregate sales performance are expected as the base-case scenario. While their numerical targets are solid, they may underestimate the size of the new market that will result from the diffusion of retail group-scale loyalty programs using smartphone apps.

Grewal and Roggeveen (2020, p. 7) state that "in the coming years, it will be of paramount importance for every retailer and service provider to have a systematic and integrated customer journey model (CJM) system in place." Meanwhile, it is also important to build and forecast an overall "customer journey" (CJM) model (aggregated sales model) from a systemic perspective as digital strategy measurement (Adner et al., 2019) to leverage the big data. The customer IDs (7iD) for brick-and-mortar stores and the loyalty program (Seven Mile Program) for smartphone apps described herein are advanced examples of digital strategies in the retail industry.

However, if the number of customers had been tracked using a dynamic model such as the one presented in this study, their market size forecast would have been different. This model takes account of the iterative transition of customer loyalty segmentation from the systemic perspective of the customer journey and the approximate calculated result of the segmented group size of loyalty program members; total performance is highly accurate. Furthermore, it can predict factors including the uncertainty of the market size. These presentations are the theoretical contribution of this study.

The research implication of this study is that the retail industry's digital strategy should be more focused on estimating and forecasting the average amounts of customer segments and the number of aggregated customers through the digitalization on the customer side than individual customer journeys and responses. This suggestion is consistent with previous research stating the key features of digital strategy are connection, aggregation and focus on forecasting (Adner et al., 2019). Modern retail companies tend to collect big data, perform statistical analysis and seek to attain insights from the results (Santoro et al., 2019). However, there may not be much interest in understanding and managing customer journey from a systemic view by developing and executing a dynamic model. The practical implication of this study is that multi-scenario evaluation through simulation of dynamic models from a systemic view can be used for decision-making in retailing digital strategies.

The limitations of this study provide opportunities for future research. This study sets several kinds of customer experience rates, by calibration. The formula for them might be defined by multiple explanatory variables. Additionally, in this study, we could not prepare the data to prove the validity of the range of the initial value (mean and standard deviation) of pink noise for market size prediction. Thus, there is scope for future research to address these matters.

\section{References}

Adner, R., Puranam, P. and Zhu, F. (2019), "What is different about digital strategy? From quantitative to qualitative change”, Strategy Science, Vol. 4 No. 4, pp. 251-342, doi: 10.1287/stsc.2019.0099. 
Baloglu, S. (2002), "Dimensions of customer loyalty: separating friends from well wishers", Cornell Hotel and Restaurant Administration Quarterly, Vol. 43 No. 1, pp. 47-59, doi: 10.1177/ 0010880402431005.

Bass, F.M. (1969), “A new product growth for model consumer durables”, Management Science, Vol. 15 No. 5, pp. 215-227, doi: 10.1287/mnsc.15.5.215.

Bowen, J.T. and Shoemaker, S. (1998), "Loyalty: a strategic commitment”, Cornell Hotel and Restaurant Administration Quarterly, Vol. 39 No. 1, pp. 12-25, doi: 10.1177/001088049803900104.

Chen, J.-S., Tsou, H.-T., Chou, C.Y. and Ciou, C.-H. (2019), "Effect of multichannel service delivery quality on customers' continued engagement intention: a customer experience perspective", Asia Pacific Journal of Marketing and Logistics, Vol. 32 No. 2, pp. 473-494, doi: 10.1108/APJML12-2018-0508.

de Haan, E., Kannan, P.K., Verhoef, P.C. and Wiesel, T. (2018), "Device switching in online purchasing: examining the strategic contingencies”, Journal of Marketing, Vol. 82 No. 5, pp. 1-19, doi: 10. 1509/jm.17.0113.

Deif, A.M. and Elmaraghy, H.A. (2009), "Modelling and analysis of dynamic capacity complexity in multi-stage production", Production Planning and Control, Vol. 20 No. 8, pp. 737-749, doi: 10. 1080/09537280903119072.

Dick, A.S. and Basu, K. (1994), "Customer loyalty: toward an integrated conceptual framework", Journal of the Academy of Marketing Science, Vol. 22 No. 2, pp. 99-113, doi: 10.1177/ 0092070394222001.

Dooley, K.J. and Van de Ven, A.H. (1999), "Explaining complex organizational dynamics", Organization Science, Vol. 10 No. 3, pp. 215-376, doi: 10.1287/orsc.10.3.358.

Forrester, J.W. (1961), Industrial Dynamics, Productivity Press, Cambridge.

Gable, M., Fiorito, S.S. and Topol, M.T. (2008), "An empirical analysis of the components of retailer customer loyalty programs", International Journal of Retail and Distribution Management, Vol. 36 No. 1, pp. 32-49, doi: 10.1108/09590550810846983.

Grewal, D. and Roggeveen, A.L. (2020), "Understanding retail experiences and customer journey management”, Journal of Retailing, Vol. 96 No. 1, pp. 3-8, doi: 10.1016/j.jretai.2020.02.002.

Handarkho, Y.D. (2020), "Understanding mobile payment continuance usage in physical store through social impact theory and trust transfer", Asia Pacific Journal of Marketing and Logistics, Vol. 33 No. 4, pp. 1071-1087, doi: 10.1108/APJML-01-2020-0018.

Jo, W., Kim, J.J. and Choi, J. (2020), "Who are the multichannel shoppers and how can retailers use them? Evidence from the French apparel industry", Asia Pacific Journal of Marketing and Logistics, Vol. 33 No. 1, pp. 250-274, doi: 10.1108/APJML-05-2019-0317.

Lemon, K.N. and Verhoef, P.C. (2016), "Understanding customer experience throughout the customer journey", Journal of Marketing, Vol. 80 No. 6, pp. 69-96, doi: 10.1509/jm.15.0420.

Lewis, C.D. (1982), Industrial and Business Forecasting Methods, Butterworth Scientific, London.

Mahajan, V., Muller, E. and Bass, F.M. (1990), "New product diffusion models in marketing: a review and directions for research", Journal of Marketing, Vol. 54 No. 1, pp. 1-26, doi: 10.2307/ 1252170.

Pan, Y., Sheng, S. and Xie, F.T. (2012), "Antecedents of customer loyalty: an empirical synthesis and reexamination”, Journal of Retailing and Consumer Services, Vol. 19 No. 1, pp. 150-158, doi: 10. 1016/j.jretconser.2011.11.004.

Pansari, A. and Kumar, V. (2017), "Customer engagement: the construct, antecedents, and consequences", Journal of the Academy of Marketing Science, Vol. 45 No. 3, pp. 294-311, doi: 10.1007/s11747-016-0485-6.

Ryutsuu News (2018a), "Seven-Eleven/Profitable new app that allows you to participate in coupon distribution and lottery", available at: https://www.ryutsuu.biz/it/k033023.html (accessed 30 March 2018). 
APJML 34,3

Ryutsuu News (2018b), "Seven and i/group crossing program 'seven miles' started, 10 million DL target”, available at: https://www.ryutsuu.biz/promotion/k051442.html (accessed 14 May 2018).

Rutsuu News (2019a), "Seven-Eleven/As of the end of December 2018, the number of app DLs was 79.70 million, and the presentation rate was a challenge", available at: https://www.ryutsuu.biz/ it/1011644.html (accessed 16 January 2019).

Ryutsuu News (2019b), "Seven and i/Group apps cumulative total exceeded 10 million downloads", available at: https://www.ryutsuu.biz/it/1021327.html (accessed 13 February 2019).

Santoro, G., Fiano, F., Bertoldi, B. and Ciampi, F. (2019), "Big data for business management in the retail industry", Management Decision, Vol. 57 No. 8, pp. 1980-1992, doi: 10.1108/MD-072018-0829.

Seven and i Holdings Co., Ltd (2019a), "Seven and i management report", available at: https://www. 7andi.com/ir/library/mr.html (accessed 26 June 2019).

Seven and i Holdings Co., Ltd (2019b), "Regarding the announcement of the discontinuation of the '7pay' service, the history of the past, and the explanation of future correspondence", available at: https://www.7andi.com/company/news/release/201908011500.html (accessed 1 August 2019).

Sterman, J.D. (2000), Business Dynamics: Systems Thinking and Modeling for a Complex World, McGraw-Hill, Boston.

Tanford, S. and Baloglu, S. (2012), "Applying the loyalty matrix to evaluate casino loyalty programs", Cornell Hospitality Quarterly, Vol. 54 No. 4, pp. 333-346, doi: 10.1177/1938965512464694.

Tanford, S. and Malek, K. (2015), "Segmentation of reward program members to increase customer loyalty: the role of attitudes towards green hotel practices", Journal of Hospitality Marketing and Management, Vol. 24 No. 3, pp. 314-343, doi: 10.1080/19368623.2014.907759.

van Heerde, H.J., Dinner, I.M. and Neslin, S.A. (2019), "Engaging the unengaged customer: the value of a retailer mobile app", International Journal of Research in Marketing, Vol. 36 No. 3, pp. 420-438, doi: 10.1016/j.ijresmar.2019.03.003.

\section{Corresponding author}

Makoto Kimura can be contacted at: mkimura@nuis.ac.jp

For instructions on how to order reprints of this article, please visit our website:

www.emeraldgrouppublishing.com/licensing/reprints.htm

Or contact us for further details: permissions@emeraldinsight.com 